Froman, C. (1968). British Fournal of Anaesthesia, 40, 354.

Frowein, R. A. (1963). Zentralc Atemstörungen bei Schädel-Hirn-Verletzungen und bei Hirntumoren. Berlin, Springer.

Heiskanen, O. (1964). Acta Neurologica Scandinavica, 40, Suppl. No. 7 Heiskanen, O., and Sipponen, P. (1970). Acta Neurologica Scandinavica, $46,343$.

Johnston, I. H., Johnston, J. A., and Jennett, W. B. (1970). Lancet, 2, 433.

Kaste, M. (1970). Experimental brain injury. Its effects on cerebral sinus pressure, cerebral venous oxygen tension, respiration, blood pressure and acid-base balance. University of Helsinki.

Keats, J. (1948). In The Letters of Fohn Keats, ed. M. Buxton Forman, p. 526. Oxford, Oxford University Press.
Lundberg, N., Troupp, H., and Lorin, H. (1965). Fournal of Neurosurgery, 22,581 .

Naeraa, N. (1967). Aendringer i lungefunktion og syre-base status hos bevidstlose neurokirurgiske patienter. University of Arhus.

Richardson, A., Hide, T. A. H., and Eversden, I. D. (1970). Lancet, 2, 687. Richardson, A., Hide, T. A. H., and Eversden,
Troupp, H. (1965). Fournal of Trauma, 5,373 .

Troupp, H. (1965). Fournal of Trauma, 5, 373.

Vapalahti, M. (1970). Intracranial pressure, acid-base status of blood and cerebrospinal fluid, and pulmonary function in the prognosis of severe brain injury. University of Helsinki.

Vapalahti, M., Troupp, H., and Heiskanen, O. (1969). In Cerebral Blood Flow', ed.' M. Brock, C. Fieschi, D. H. Ingvar, N. A. Lassen, and K. Schürmann, p. 266. Berlin, Springer.

\title{
Nitroprusside Revisited
}

\section{K. MANI}

British Medical fournal, 1971, 3, 407-408

\section{Summary}

Sodium nitroprusside is a readily available, powerful hypotensive agent. It was administered intravenously in four cases when all other available hypotensive agents had failed, and blood pressure was controlled promptly and with no side effects. This is a valuable drug and deserves wider use.

\section{Introduction}

The value of sodium nitroprusside in the treatment of hypertensive emergencies is well established. However, it has been little used because it is thought to be too toxic. In my experience of the drug, limited to four patients, I found it effective and safe.

\section{Methods}

A solution of sodium nitroprusside containing $50 \mathrm{mg}$ of the drug in a litre of $5^{\circ}{ }_{0}^{\prime}$ dextrose solution was made up according to the method described by Gifford (1970). This was administered as an intravenous drip. Blood pressure was recorded continuously during the first 10 minutes by a standard sphygmomanometer, the cuff being deflated fully after each reading, and thereafter every 10 minutes while the infusion was maintained. The quantities of sodium nitroprusside used in each case and the period for which they were infused are given in Table $\mathrm{I}$.

TABLE I-Amount of Sodium Nitroprusside Infused in Four Cases and Period over which it was Administered

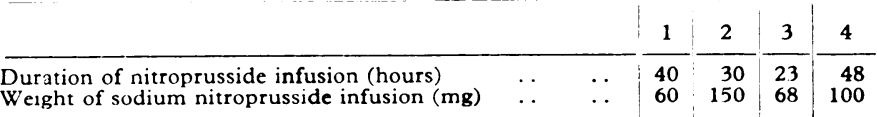

\section{Case Report}

Case 1.-A 37-year-old man had a two-year history of hypertension. Six weeks before he entered hospital his blood pressure

\section{Sydney Hospital, Sydney, Australia}

M. K. MANI, M.D., Physician to Renal, Dialysis, and Transplant Units (Present address: Stanley Medical College, Madras, India) began to rise despite continuing treatment and his renal function began to deteriorate. On admission he had a blood pressure of $210 / 150 \mathrm{~mm} \mathrm{Hg}$, a grade IV hypertensive retinopathy, pulmonary oedema, and a serum creatinine level of $16.3 \mathrm{mg} / 100 \mathrm{ml}$. Treatment with clonidine $900 \mathrm{mg}$, debrisoquine $40 \mathrm{mg}$, and ethacrynic acid 200 $\mathrm{mg}$ daily, together with reserpine $12 \mathrm{mg}$ intramuscularly daily for the first two days and pentolinium $50 \mathrm{mg}$ subcutaneously daily for the next two days, had no effect on the blood pressure. Diazoxide $600 \mathrm{mg}$ intravenously on the fifth day was also ineffectual. Peritoneal dialy' is was instituted to try to control azotaemia before bilateral nephrectomy (Stokes et al., 1970) and to attempt to lower the blood pressure by dehydration. He lost $10 \mathrm{~kg}$ in weight after 24 hours of dialysis, but his blood pressure rose to $270 / 170 \mathrm{~mm} \mathrm{Hg}$. An infusion of sodium nitroprusside then controlled the blood pressure satisfactorily (Table II). Bilateral nephrectomy was carried out, blood pressure returned to normal, and no further medication was required. The patient received a renal allograft a year later.

Case 2.-A 54-year-old man had a two-year history of hypertension for which he was receiving treatment. On admission he was drowsy and disorientated. The blood pressure was $240 / 170 \mathrm{~mm}$ $\mathrm{Hg}$, there was an early diastolic murmur over the aortic and left parasternal area, grade IV hypertensive retinopathy was present, and the serum creatinine level was $15.3 \mathrm{mg} / 100 \mathrm{ml}$. An infusion of sodium nitroprusside rapidly lowered the blood pressure (Table II), but the serum creatinine level remained high and the cerebral state did not improve. Peritoneal dialysis was instituted, but he died eight hours later.

TABLE II-Blood pressure control with sodium nitroprusside and other antihypertensive agents. The figures are the means of all the systoli: and diastolic readings taken in the lying position during the patients' stay in Hospital before readings taken in the lying position during the patients' stay in Hospital before
and during the infusion of sodium nitroprusside. Standard deviation of each set and during the infusion of sodium nitro
of readings is given in parentheses

\begin{tabular}{|c|c|c|c|c|c|}
\hline & \multirow[t]{2}{*}{ Case No. } & \multicolumn{2}{|c|}{$\begin{array}{l}\text { B.P. in } \mathrm{mm} \mathrm{Hg} \text { on Other } \\
\text { Antihypertensive Agents }\end{array}$} & \multicolumn{2}{|c|}{$\begin{array}{l}\text { B.P. in } \mathrm{mm} \mathrm{Hg} \text { during } \\
\text { Administration of } \\
\text { Nitroprusside }\end{array}$} \\
\hline & & Mean (S.D.) & Range & Mean (S.D.) & Range \\
\hline 1 & . & $\frac{220(29)}{140(11)}$ & $\frac{160-270}{120-170}$ & $\frac{157(20)}{105(13)}$ & $\frac{90-180}{80-130}$ \\
\hline 2 & & $\frac{237(8)}{163(6)}$ & $\frac{220-240}{160-170}$ & $\frac{160(9)}{100(8)}$ & $\frac{150-170}{90-110}$ \\
\hline 3 & . & $\frac{169(28)}{127(21)}$ & $\frac{100-220}{60-170}$ & $\frac{146(19)}{97(13)}$ & $\frac{100-200}{60-130}$ \\
\hline $4^{*}$ & . & $\frac{168(37)}{120(27)}$ & $\frac{90-230}{70-170}$ & $\frac{130(17)}{96(7)}$ & $\frac{100-150}{80-105}$ \\
\hline
\end{tabular}

*The readings while the patient was on peritoneal dialysis have been omitted (see text).

Case 3.-A 29-year-old man had had no symptoms until five days before admission when he developed blurring of vision, and on the morning of admission frank haematuria developed. His 
blood pressure was $220 / 170 \mathrm{~mm} \mathrm{Hg}$, he had grade IV hypertensive retinopathy, and the serum creatinine level was $5.0 \mathrm{mg} / 100 \mathrm{ml}$. He still felt well. Diazoxide $300 \mathrm{mg}$ intravenously lowered the blood pressure, but methyldopa, debrisoquin, reserpine, and clonidine failed to maintain control. There was pronounced orthostatic hypotension, but the blood pressure in the lying posture was high. Renal biopsy showed severe hypertensive nephropathy with many hyalinized glomeruli, the serum creatinine rose to $11.3 \mathrm{mg} / 100 \mathrm{ml}$, and there were bouts of left ventricular failure. It was decided to perform bilateral nephrectomy, and an infusion of sodium nitroprusside readily controlled the blood pressure (Table II). At the time of writing he was awaiting a renal transplant and his blood pressure was under control without drugs.

Case 4.-A 48-year-old man had a 10-month history of hypertension and renal failure. Control of hypertension had become in creasingly difficult, and on admission the blood pressure was 230/ $150 \mathrm{~mm} \mathrm{Hg}$, the serum creatinine $13.0 \mathrm{mg} / 100 \mathrm{ml}$, and there was a grade IV hypertensive retinopathy. Pentolinium, $25 \mathrm{mg}$ subcutaneously in 12 hours, had no effect on the blood pressure, but it fell briefly to $90 / 70 \mathrm{~mm} \mathrm{Hg}$ after $300 \mathrm{mg}$ of diazoxide intravenously. Sodium nitroprusside was then used with good effect. It was continued during peritoneal dialysis preparatory to bilateral nephrectomy, but there were pronounced swings in blood pressuresystolic 80-260, mean 156 (S.D.43); diastolic 50-160, mean 112 (S.D.28)-with severe anginal pain. There was no evidence of myocardial infarction. Sodium nitroprusside was continued after dialysis ended and blood pressure control again became satisfactory and the anginal pain ceased. After bilateral nephrectomy his blood pressure returned to normal without further therapy, but unfortunately he died six days after the operation from bronchopneumonia and septicaemia.

\section{Discussion}

Sodium nitroprusside has a direct depressant effect on vascular musculature, independent of the nervous system (Page et al., 1955). The effect is immediate and ends when the infusion is stopped. The latter property is of special value in patients in whom the cause of hypertension is to be abruptly removed. I have not used the drug during surgery for a phaeochromocytoma, but it would seem to be the drug of choice for this purpose and for when controlled lowering of blood pressure is needed during surgery. Though it is less effective in normotensive subjects than in hypertensives it produces a fall of blood pressure, and Kaneko et al. (1967) used it rapidly to lower the blood pressure in normotensive subjects to study renin release.

The drug is virtually non-toxic during short-term use. Long-term toxic effects are due to accumulation of thiocyanate, to which sodium nitroprusside is converted. One case reported by Nourok et al. (1964) developed high serum levels of thiocyanate and features of hypothyroidism after 21 days, which improved when the nitroprusside infusion was stopped. The longest period of infusion in my cases was 48 hours, and no toxic effects were observed. The swinging blood pressure and anginal pain in Case 4 were undoubtedly associated with peritoneal dialysis.

We have here an effective, safe, cheap, and readily available agent for the treatment of hypertensive emergencies. An obvious reason why it has not been more generally used is its potency and the care which must be taken during its administration, especially during the first few minutes until the correct rate of infusion is arrived at. This is not a real objection to the use of an agent with so many advantages.

I am indebted to the registrars, residents, and nursing staff of the renal unit of Sydney Hospital, whose hard work and careful attention made the use of the drug possible, and to Dr. J. H. Stewart, who was an unfailing source of encouragement.

\section{References}

Gifford, R. W. (1970). In Drugs of Choice, 1970-71, ed. W. Modell, p. 386. Saint Louis, Mosby

Kaneko, Y., Ikeda, T., Takeda, T., and Ueda, H. (1967). fournal of Clinical Investigation, 46, 705 .

Nourok, D. S., Glassock, R. J., Solomon, D. H., and Maxwell, M. H. (1964). American fournal of the Medical Sciences, 248, 129.

Page, I. H., Corcoran, A. C., Dustan, H. P., and Koppanyi, T. (1955). Circulation, 11, 188.

Stokes, G. S., Mani, M. K., and Stewart, J. H. (1970). British Medical fournal, 3, 126.

\title{
Infections of Scribner and Brescia Arteriovenous Shunts
}

\author{
A. J. RALSTON, \\ G. R. HARLOW, \\ D. M. JONES, \\ P. DAVIS
}

British Medical fournal, 1971, 3, 408-409

\section{Summary}

The incidence of infections of Scribner shunts and Brescia fistulae in patients receiving intermittent haemodialysis was compared. In both groups infection was most commonly due to Staphylococcus aureus and was associated especially with carriage of this organism on the skin of the limb where the shunt or fistula was sited. The incidence of local infection was much less with the

\section{University Hospital of South Manchester, Manchester M20 8LR}

A. J. RALSTON, M.B., M.R.C.P., Consultant Physician

G. R. HARLOW, M.B., Medical Assistant

D. M. JONES, M.D., M.R.C.PATH., Consultant Bacteriologist, Public Health Laboratory Service

P. DAVIS, F.I.M.L.T., Chief Technician
Brescia fistula but this was accompanied by a relatively higher incidence of septicaemia.

\section{Introduction}

The introduction of the Teflon arteriovenous shunt described by Scribner and his colleagues (Quinton et al., 1960) led to the treatment of chronic renal failure by intermittent haemodialysis. One of the principal complications associated with the shunt was infection (Martin et al., 1967; Curtis et al., 1969). The description of a surgically created subcutaneous arteriovenous fistula (Brescia et al., 1966) yielded an alternative method of gaining access to the circulation of the patient. Though in the original description a case of bacterial endocarditis was described, it was commonly held early on (Cohen et al., 1968; Shaldon and McKay, 1968) that one of the advantages of this technique would be the reduced incidence of infection when compared with the Scribner shunt. In this paper we describe our 